\title{
PENGARUH SHIFT KERJA TERHADAP STRESS KERJA PENGENDALI (CONTROLLER) KERETA API INDONESIA
}

\author{
${ }^{1}$ Lauditta Irianti, ${ }^{2}$ Ade Geovania, ${ }^{3}$ Hardianto Iridiastadi \\ ${ }^{1}$ Program Studi Teknik dan Manajemen Industri, Fakultas Teknologi, Institut Teknologi Nasional \\ ${ }^{2,3}$ Program Studi Teknik dan Manajemen Industri, Fakultas Teknologi, Institut Teknologi Bandung \\ lauditta.irianti@gmail.com ${ }^{1}$, adex_ahla@yahoo.com ${ }^{2}$, hiridias@vt.edu ${ }^{3}$
}

\begin{abstract}
Abstrak-- Keselamatan kereta api merupakan permasalahan yang memerlukan perhatian lebih, mengingat moda transportasi ini merupakan moda yang banyak digunakan oleh masyarakat. Pengendali adalah salah satu divisi yang sangat mempengaruhi kelancaran dan keselamatan perjalanan kereta api, sehingga performansi kerja yang baik merupakan tuntutan yang sangat tinggi bagi divisi tersebut. Shift kerja adalah salah satu faktor yang dapat mempengaruhi performansi kerja manusia. Shift kerja terbukti mempengaruhi kelelahan, kantuk dan lainnya, namun hingga saat ini masih terdapat beberapa pendapat mengenai keterkaitan antara shift kerja dan stres kerja. Tujuan penelitian ini adalah untuk mengevaluasi pengaruh shift kerja terhadap stres kerja pengendali kereta api. 17 partisipan adalah pegawai pengendali kereta api stasiun besar kelas $A$ Daerah Operasi (DAOP) II Bandung. Alat ukur yang digunakan adalah cocorometer. Cocorometer digunakan untuk mengukur kadar $\alpha$ - amilase dalam air liur. Pengolahan data dilakukan dengan Uji Statistika Friedman dan dilanjutkan dengan uji Post Hoc Bonferonni jika terbukti signifikan. Hasil penelitian ini menunjukkan bahwa shift kerja tidak signifikan mempengaruhi tingkat stres kerja $(P>0,10)$. Meskipun begitu, hasil pengukuran pada seluruh partisipan untuk setiap shift sangat tinggi (120-135 kU/l), dan nilai tertinggi dihasilkan saat shift siang. Hal ini menunjukkan tingkat stres kerja sangat tinggi dan tidak dipengaruhi oleh shift kerja. Berdasarkan penelitian ini, tindakan perbaikan terhadap sistem shift pada PT. Kereta Api Indonesia (KAI) tidak terlalu perlu dilakukan namun diperlukan peninjauan kembali terhadap faktor lain yang dapat mempengaruhi tingkat stres kerja, seperti karateristik pekerjaan, beban kerja, lingkungan kerja ataupun faktor individu.
\end{abstract}

Kata kunci: shift kerja, stres kerja, pengendali, controller, $\alpha$ amilase, kereta api

\section{PENDAHULUAN}

Kereta api merupakan salah satu transportasi darat yang banyak digunakan oleh masyarakat. Hal ini dikarenakan kereta api merupakan transportasi yang yang memiliki jalur tersendiri sehingga tidak akan terpengaruh akan hambatan kepadatan jalan raya, serta memiliki rute tujuan yang cukup banyak. Kecelakaan kereta api merupakan suatu permasalahan yang serius. Berdasarkan data Kementerian Perhubungan Indonesia, tingkat kecelakaan kereta api telah menurun sekitar 57\% sejak tahun 2009 hingga 2013. Meskipun demikian, kecelakaan kereta api tetap membutuhkan perhatian yang tinggi dikarenakan tingginya tingkat penggunaan masyarakat terhadap sarana tersebut

Salah satu divisi terpenting pada kereta api adalah divisi pengendali (Controller). Petugas pengendali adalah bagian operasional yang bertugas untuk mengontrol perjalanan kereta api baik dalam satu daerah operasi ataupun dalam stasiun, mengawasi lintasan yang akan dilalui kereta, pembatalan dan pengumuman perjalanan kereta api serta perubahan atau penambahan perjalanan pada stasiun setempat. Petugas pengendali dituntut untuk selalu konsentrasi, waspada, teliti, sigap dan cepat dalam bertindak. Selain tuntutan kerja yang tinggi, petugas pengendali pun bekerja dengan sistem shift. Petugas pengendali bekerja selama 5 hari dengan 2 hari libur. Dalam sehari, kereta api beroperasi selama 21 jam, sehingga dibutuhkan sistem shift kerja untuk petugas pengendali. Sistem shift terdiri dari 3 shift, yaitu shift pagi, shift siang dan shift malam.

Performansi kerja petugas pengendali yang baik sangat dibutuhkan, karena hal tersebut sangat menunjang kelancaran dan keamanan perjalanan kereta api. Beberapa penelitian tentang kereta api terpusat kepada masinis [1], [2], [3], [4] namun masih sedikit penelitian mengenai petugas pengendali [5]

Salah satu faktor yang mempengaruhi performansi kerja manusia adalah tuntutan pekerjaan dimana salah satu ruang lingkupnya adalah shift kerja [6], [7], [8], [9]. Shift kerja saat ini telah banyak diterapkan dan dianggap lazim, hal tersebut akhirnya berpengaruh terhadap sistem yang ditetapkan kepada 20\% hingga $25 \%$ pekerja di industri maupun jasa [10]. Shift kerja adalah jadwal pekerjaan diluar standar jam normal dimana dapat terjadi pertukaran atau pergantian pekerjaan antara satu individu atau grup kerja kepada individu atau grup lain [10], [11].

Penelitian sebelumnya mengenai shift kerja dilakukan terhadap beberapa objek seperti jasa kesehatan [12], [13], 
pengemudi transportasi [2],[3], operator [14],[15] dan petugas polisi [16]. Penelitian sebelumnya menunjukkan bahwa shift kerja mempengaruhi tingkat kelelahan [2],[9], [17], kantuk [3], [16], [9], [18], gangguan sosial [16],[21], gangguan kesehatan [16],[19], [20], gangguan fungsi kognitif [22], gangguan konsentrasi kerja [16], serta meningkatkan risiko kecelakaan kerja [23] dimana hal tersebut pada akhirnya akan berdampak kepada performansi kerja manusia [24].

Tingkat kantuk dan kelelahan paling tinggi terjadi saat shift awal pagi dan shift malam (Ingre dkk., 2004 dalam [3], [9], [25]). Spencer (1987) dalam [6] mendeskripsikan bahwa performansi kerja paling buruk terjadi saat jam kerja dimulai terlalu malam hingga pagi dan perfomansi kerja terbaik terjadi saat jam kerja dimulai dari pagi hari hingga sore hari. Performansi kerja yang buruk memungkinkan timbulnya risiko kecelakaan kerja. Hanecke dkk. (1998) dalam [6] mendeskripsikan risiko kecelakaan kerja terhadap pekerja shift. Bagi pekerja shift pagi yang dimulai pukul 06.00, risiko kecelakaan kerja terjadi setelah pukul 13.00. Bagi pekerja saat shift siang, yang dimulai pukul 14.00, risiko kecelakaan kerja terjadi setelah pukul 21.00, dan bagi pekerja shift malam, yang dimulai pukul 22.00 , risiko kecelakaan terjadi setelah pukul 05.00.

Hingga saat ini masih terdapat beberapa pendapat mengenai pengaruh shift kerja terhadap stres kerja. Park [26] mendeskripsikan bahwa terdapat perbedaan yang signifikan antara pekerja shift dan non-shift terhadap tingkat stres kerja. Pekerja shift mengalami tingkat stres kerja yang lebih tinggi. Meskipun begitu, penelitian lain mendeskripsikan bahwa shift kerja tidak mengakibatkan stres kerja, namun kondisi dan situasi kerjalah yang mengakibatkan timbulnya hal tersebut [17]. Gerber dkk., [16] mendeskripsikan bahwa shift kerja tidak mempengaruhi secara langsung terhadap stres kerja, namun diakibatkan oleh rasa kantuk yang sangat tinggi dan kesehatan yang memburuk. Namun di sisi lain, Srivastava [27] kembali membuktikan bahwa shift kerja mempengaruhi tingkat stres kerja dan mood manusia sehingga pada akhirnya berpengaruh kepada kesehatan manusia.

Stres adalah reaksi yang tidak diinginkan timbul pada seseorang dalam menghadapi stimulus berupa tekanan atau tuntutan dari luar [28],[29]. Stres kerja adalah reaksi negatif yang dapat membahayakan bagi fisik dan emosional manusia yang timbul akibat ketidakmampuan manusia dalam menghadapi tuntutan lingkungan kerja, seperti persyaratan pekerjaan yang tidak sesuai dengan kemampuan, sumber daya serta kebutuhan manusia (National Institute of Occupational Safety and Health, 1999 dalam [26].). Stres kerja dapat dipandang sebagai disfungsional bagi organisasi dan anggotanya (Kahn dkk., 1964, dalam [29]).

Slaven dalam [6] mendeskripsikan penyebab stres kerja ke dalam lima hal, yaitu tuntutan pekerjaan, peraturan perusahaan, hubungan sosial dalam bekerja, pengembangan karir, dan iklim organisasi. Dideskripsikan pula bahwa salah satu gejala stres kerja adalah timbulnya perubahan pada fisiologi individu, seperti meningkatnya tekanan darah dan risiko sakit jantung. Di samping itu terdapat gejala fisiologis lainnya yaitu meningkatnya tingkat kortisol dalam darah (Vander dan Luciano, 2001 dalam [30]; Kirschbaum dan Hellhammer, 1994 dalam [31]) serta tingkat amilase pada air liur [28], [32], [33]. Selain adanya perubahan fisiologis, stres kerja dapat mengakibatkan gangguan kesehatan bahkan keselamatan manusia dan pada akhirnya mengakibatkan tingginya turnover pekerja bahkan tingkat absensi pekerja. ([14]; [19]; Slaven dalam [6])

Denyut jantung dan tekanan darah seringkali digunakan untuk mengukur stres psikologi manusia, namun memiliki beberapa kelemahan. Yamaguchi dkk [28] mendeskripsikan bahwa pengukuran tersebut tidak dapat membedakan eustress (stres positif) dan distress (stres negatif). Selain itu, pengukuran ini dipengaruhi oleh sistem homeostasis manusia juga perubahan pada indeks pengukuran tersebut tidak terlalu berbeda dengan nilai normalnya. Metoda pengukuran lainnya yang sering digunakan dalam mengukur stres kerja adalah hormon kortisol dan norephinephrine. Namun, kedua metoda tersebut cukup sulit dilakukan dan membutuhkan waktu yang lama (Kirschbaum and Hellhammer, 1989, 1994 dalam [28]). Beberapa penelitian mendeskripsikan bahwa terdapat metoda lain dalam mengukur tingkat stres manusia, yaitu dengan mengukur kadar amilase dalam air liur [31], [28].

Yamaguchi dkk., [28] mendeskripsikan bahwa sekresi amilase pada air liur diatur oleh simpatik-adrenomedullary (sistem SAM) yang dikendalikan oleh norepinefrin (adrenal) dalam kelenjar air liur. Dalam sistem SAM, terdapat dua sistem regulasi, yaitu regulasi hormonal dan saraf langsung. Penggunaan regulasi hormonal dalam pendeteksian stres memiliki masalah, karena perubahan dalam tingkat neropinefrin tertunda sekitar 20-30 menit dalam menanggapi beban stres. Sebaliknya, sekresi amilase dalam air liur apabila dirangsang oleh saraf langsung akan menanggapi lebih cepat, sekitar satu hingga beberapa menit, jika dibandingkan dengan regulasi hormonal. Ketika aktivitas amilase pada air liur dimonitor, kelenjar air liur tidak hanya bertindak sebagai penguat bahwa tingkat neropinefrin rendah, tetapi juga lebih cepat dan sensitif dalam menanggapi stres psikologi jika dibandingkan dengan kortisol. Penelitian sebelumnya mendeskripsikan bahwa aktivitas amilase ada air liur berada di rentang 5,5 kU/1 hingga 144,4 kU/1 [28] dan 19 kU/1 hingga 308 kU/1 (Takai dkk., 2004 dalam [34]).

Tujuan dari penelitian ini adalah untuk mengevaluasi hubungan antara shift kerja terhadap tingkat stres kerja pekerja pengendali (controller) kereta api Indonesia. Terdapat dua hipotesis pada penelitian ini, yaitu: (1) shift kerja mempengaruhi tingkat stres kerja manusia; (2) Tingkat stres tertinggi terjadi pada saat shift malam. 


\section{METODOLOGI PENELITIAN}

A. Partisipan

Partisipan adalah seluruh pegawai pengendali kereta api (rata-rata umur 36 tahun \pm 6.7 ), berjumlah 21 orang, yang bekerja di DAOP II stasiun besar kelas A Bandung, Indonesia. Seluruh pengendali berjenis kelamin pria. Terdapat empat partisipan yang berhenti pada saat penelitian masih berlangsung, hal ini diakibatkan oleh keputusan perusahaan untuk mentransfer partisipan ke daerah lain, sehingga total partisipan hingga akhir adalah 17 pegawai.

Seluruh partisipan tidak memiliki sejarah penyakit baik fisik maupun mental. Sekitar $47 \%$ partisipan memiliki kebiasaan merokok dan sekitar $41 \%$ partisipan memiliki kebiasaan meminum kopi di saat bekerja. Rata-rata partisipan memiliki pengalaman bekerja sebagai pengendali selama $9 \pm 8$ bulan. Para partisipan telah bekerja sangat lama di PT.KAI namun seringkali mengalami rotasi pekerjaan. Hal ini dikarenakan sistem perusahaan yang mewajibkan setiap karyawannya mengalami rotasi pekerjaan yang dirasa cukup sesuai dengan kapabilitas karyawan.

\section{B. Sistem Shift Kerja}

Partisipan bekerja dalam tiga shift yaitu shift pagi (08.00-14.00), shift siang (14.00-20.00), dan shift malam (20.00-08.00). Durasi bekerja untuk shift pagi dan siang adalah enam jam dan untuk shift malam adalah 12 jam. Pada saat shift malam terdapat waktu kosong selama tiga jam, antara pukul 00.00-03.00 dikarenakan tidak adanya jadwal perjalanan kereta api, sehingga durasi efektif bekerja menjadi sembilan jam. Sistem shift yang diterapkan adalah sistem maju (forward) dan rotasi cepat (fast rotating). Hari libur ditetapkan setelah melaksanakan shift malam. Pola shift kerja adalah 2-2-1-2 (2 hari pagi -2 hari siang- 1 hari malam-2 hari libur).

\section{Alat Ukur}

Alat ukur yang digunakan pada penelitian ini adalah Cocorometer (Nipro Corporation, Japan). Cocorometer digunakan untuk mengukur kadar $\alpha$-amilase yang dapat digunakan untuk mengukur tingkat stress seseorang[28], [32],[33] baik stres psikologi [35] ataupun psikososial [30] dengan tingkat keakuratan sebesar 94\% jika dilakukan di bawah satu menit [36]. Unit yang digunakan adalah kU/1. Alat cocorometer dapat dilihat pada Gambar 1.

Penggunaan alat cocorometer ini dilakukan dengan memasukkan strip (sebagai wadah penempatan air liur) ke dalam mulut selama 10-30 detik [34]. Setelah itu, strip dimasukkan ke dalam alat cocorometer. Cocorometer akan menampilkan kadar amilase dalam air liur. Terdapat empat klasifikasi, yaitu stres rendah $(0-30 \mathrm{kU} / 1)$, stres normal (31$25 \mathrm{kU} / \mathrm{l})$, stres (46-60 kU/l) dan sangat stres ( $\geq 61 \mathrm{kU} / \mathrm{l})$

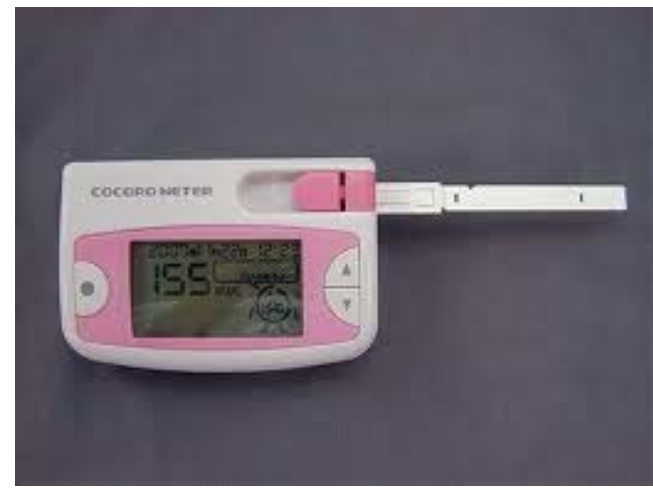

Gambar 1 Contoh cocorometer

\section{Prosedur Penelitian}

Penelitian dilakukan langsung di lapangan tempat para pegawai bekerja. Setiap partisipan melakukan penelitian pendahuluan (pra eksperimen) yang dilakukan satu minggu sebelum eksperimen dilakukan. Pada tahap ini partisipan berlatih dalam menggunakan alat-alat pengukuran. Hal ini dilakukan agar hasil penelitian tidak bias yang diakibatkan oleh ketidaktahuan partisipan dalam penggunaan alat [37].

Pada saat penelitian, partisipan diharapkan untuk tidak makan; minum alkohol, kopi ataupun soft drink ; merokok dan melakukan aktivitas fisik minimal satu jam sebelum pengukuran dilakukan [31], [38], [39] serta tidak memiliki masalah kesehatan baik fisik maupun mental, untuk menghindari pengaruh penggunaan obat [38]. Setiap partisipan akan diukur saat bekerja pada shift pagi, shift siang dan shift malam. Pada masing-masing shift, pengukuran akan dilakukan pada saat sebelum bekerja, tengah saat bekerja dan tepat setelah bekerja. Pengukuran tengah saat bekerja untuk shift pagi dan siang dilakukan dengan interval jam kerja dibagi dua yaitu tiga jam setelah waktu mulai kerja, yaitu pukul 11.00 untuk shift pagi dan 17.00 untuk shift siang. Pengukuran tengah bekerja untuk shift malam dilakukan pukul 00.00. Masing-masing responden total akan mengalami sembilan kali pengukuran (tiga kali pada setiap shift), sehingga total jumlah data untuk ke-17 responden adalah 153 data.

\section{E. Statistika}

Pengolahan data dilakukan dengan menggunakan software SPSS Statistic v20. Jumlah partisipan pada penelitian ini tidak terlalu banyak, yaitu total akhir berjumlah 17 partisipan, yang dikarenakan sulitnya perijinan dari pihak perusahaan. Berdasarkan hal tersebut maka metoda statistika yang digunakan adalah metoda non parametrik. Tipe eksperimen merupakan within-subject dengan level lebih dari dua $(\mathrm{k}>2)$. Oleh karena itu digunakan metoda statistika non parametrik Friedman-test.

Derajat kepercayaan $(\alpha)$ yang digunakan adalah $10 \%$. Hal ini berdasarkan pertimbangan bahwa penelitian ini merupakan penelitian langsung di lapangan. Meskipun pihak peneliti telah membuat prosedur sedemikian rupa, 
namun terdapat beberapa hal yang tidak dapat dikendalikan secara ketat. Jika hasil Friedman-test menunjukan adanya signifikansi maka dilanjutkan dengan melakukan uji Bonferonni-Dunn Pot Hoc [40], [41] untuk mengetahui shift mana yang paling mempengaruhi hasil pengukuran. Nilai derajat kepercayaan untuk uji Bonferonni-Dun menjadi $\alpha / \mathrm{k}$, dimana $\mathrm{k}$ adalah jumlah level yang digunakan, yaitu menjadi 0.333

\section{HASIL DAN PEMBAHASAN}

Nilai pengukuran untuk sebelum bekerja, tengah saat bekerja, dan akhir setelah bekerja dirata-ratakan terlebih dahulu sehingga satu shift akan menghasilkan satu nilai kadar $\alpha$-amilase pada masing-masing partisipan. Hal ini dapat dilihat pada Tabel I

Tabel I

RATA-RATA HASIL PENGUKURAN SETIAP PARTISIPAN

\begin{tabular}{|c|c|c|c|}
\hline \multirow{2}{*}{ Partisipan } & \multicolumn{3}{|c|}{$\begin{array}{c}\text { Rata-Rata Kadar } \alpha \text {-amilase setiap } \\
\text { partisipan (kU/l) }\end{array}$} \\
\hline & Shift Pagi & Shift Siang & Shift Malam \\
\hline 1 & 89.3 & 83.7 & 77.0 \\
\hline 2 & 88.0 & 105.0 & 99.0 \\
\hline 3 & 60.7 & 111.3 & 148.7 \\
\hline 4 & 117.0 & 130.3 & 103.3 \\
\hline 5 & 207.7 & 189.7 & 284.7 \\
\hline 6 & 113.3 & 141.0 & 98.0 \\
\hline 7 & 82.3 & 99.7 & 88.3 \\
\hline 8 & 93.7 & 152.7 & 80.0 \\
\hline 9 & 134.7 & 87.3 & 59.7 \\
\hline 10 & 64.3 & 71.7 & 55.7 \\
\hline 11 & 95.0 & 231.3 & 100.0 \\
\hline 12 & 166.0 & 125.0 & 165.0 \\
\hline 13 & 245.3 & 258.3 & 204.7 \\
\hline 14 & 120.3 & 142.7 & 104.7 \\
\hline 15 & 96.3 & 115.7 & 102.3 \\
\hline 16 & 190.0 & 86.7 & 153.3 \\
\hline 17 & 100.3 & 149.0 & 157.0 \\
\hline
\end{tabular}

Nilai rata-rata kadar $\alpha$-amilase setiap partisipan untuk setiap shift kerja dipetakan dalam diagram pencar yang dapat dilihat pada Gambar 2.

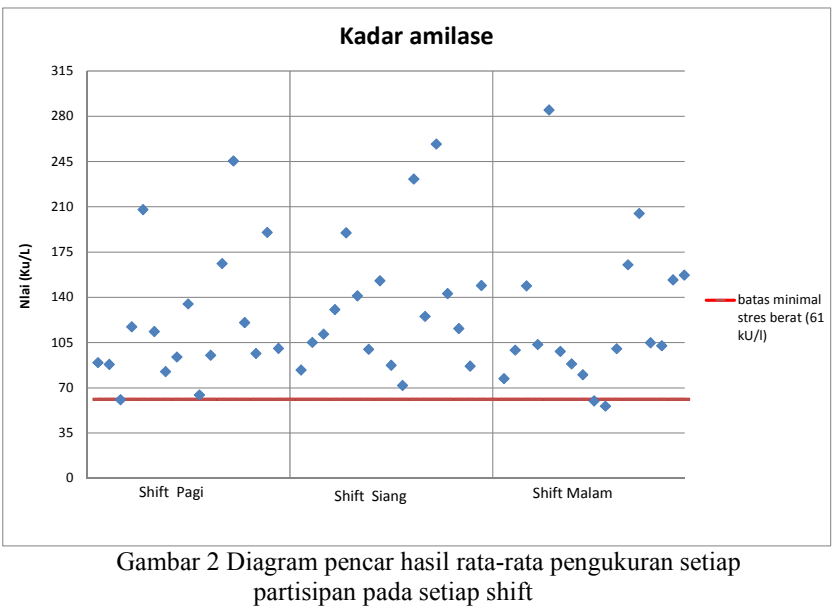

Nilai rata-rata kadar $\alpha$-amilase secara keseluruhan untuk masing-masing shift kerja dapat dilihat pada Tabel II.

TABEL II

RATA-RATA KADAR $\alpha$-AMILASE KESELURUHAN UNTUK MASINGMASING SHIFT KERJA

\begin{tabular}{|c|c|c|c|}
\hline Parameter & $\begin{array}{c}\text { Shift Pagi } \\
(\mathbf{k U} / \mathbf{l})\end{array}$ & $\begin{array}{c}\text { Shift Siang } \\
(\mathbf{k U} / \mathbf{l})\end{array}$ & $\begin{array}{c}\text { Shift Malam } \\
(\mathbf{k U} / \mathbf{l})\end{array}$ \\
\hline Rata-rata & 121.4 & 134.2 & 122.4 \\
\hline St.Deviasi & 51.8 & 51.6 & 58.0 \\
\hline Max & 245.3 & 258.3 & 284.7 \\
\hline Min & 60.7 & 71.7 & 55.7 \\
\hline
\end{tabular}

Pada Tabel II dapat dilihat bahwa rata-rata dan nilai minimum kadar $\alpha$-amilase tertinggi terjadi pada saat shift siang. Saat shift pagi dan malam, rata-rata kadar amilase tidak terlalu berbeda. Jika dilihat dari hasil standar deviasi dan nilai maksimum dari shift malam memiliki nilai standar deviasi tertinggi. Perbandingan parameter untuk setiap shift kerja dapat dilihat pada Gambar 3.

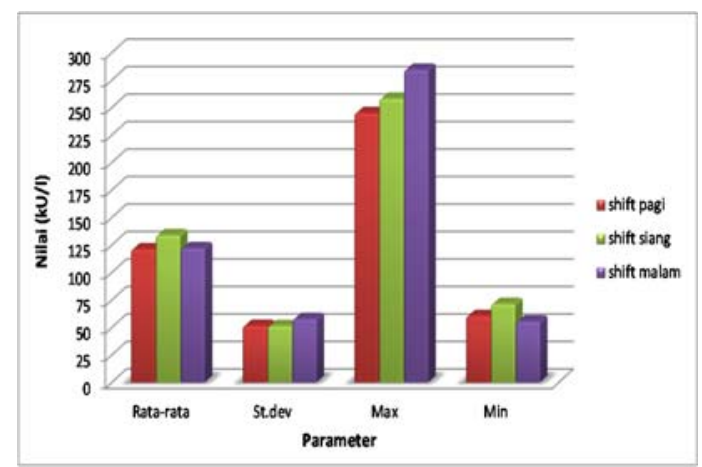

Gambar 3 Perbandingan nilai parameter setiap shift kerja

Pada Gambar 2 dapat dilihat bahwa penyebaran nilai kadar amilase untuk ketiga shift sebagian besar berada pada rentang $70 \mathrm{kU} / 1$ hingga $140 \mathrm{kU} / \mathrm{l}$. Pengujian statistika dengan Friedman test dan hasil uji tersebut adalah nilai $p>0.10$. Nilai statistik menunjukkan bahwa shift kerja tidak signifikan mempengaruhi tingkat stres kerja. Berdasarkan 
Tabel II, pada saat shift siang dan malam, kadar $\alpha$-amilase meningkat sekitar hingga sekitar $10 \%$ jika dibandingkan shift pagi. Namun, kadar $\alpha$-amilase saat shift malam menurun sekitar 9\% jika dibandingkan dengan shift siang.

Jika dilihat pada Gambar 2, nilai kadar $\alpha$-amilase setiap partisipan pada setiap shift sebagian besar lebih besar dari $60 \mathrm{kU} / 1$, dimana hal tersebut menunjukkan tingkat stres yang sangat tinggi. Saat shift pagi, sekitar 94\% partisipan menghasilkan nilai di atas $60 \mathrm{kU} / 1$. Saat shift siang, seluruh partisipan menghasilkan nilai di atas $60 \mathrm{kU} / \mathrm{l}$. Saat shift malam, sekitar $88 \%$ partisipan menghasilkan nilai di atas 60 kU/1. Nater dkk., [31] mendeskripsikan bahwa nilai kadar $\alpha$-amilase akan tinggi di saat manusia menerima stressor (hal yang mengakibatkan stress) baik secara fisiologi atau psikologi. Namun yang menarik pada penelitian ini adalah kadar $\alpha$-amilase para partisipan yang dihasilkan sangat tinggi di seluruh shift.

Penelitian sebelumnya mendeskripsikan bahwa banyaknya shift malam tidak mempengaruhi stres kerja, namun psikososial dan lingkungan yang mempengaruhi [15]. Berdasarkan wawancara yang dilakukan, para partisipan tidak merasakan rasa tertekan dalam bekerja. Gerber dkk, [16] menyebutkan bahwa shift kerja tidak signifikan mempengaruhi stress kerja secara langsung, namun stress kerja diakibatkan karena meningkatnya kurang tidur serta penurunan kesehatan tubuh.

Berdasarkan hipotesis penelitian ini, seharusnya tingkat stres kerja tertinggi terjadi saat shift malam. Namun, jika dilihat pada Tabel I, pola kenaikan dan penurunan kadar $\alpha$-amilase setiap partisipan berbeda-beda. Sekitar 59\% partisipan mengalami pola kadar $\alpha$-amilase meningkat saat shift siang jika dibandingkan shift pagi dan menurun kembali saat shift malam. Sekitar $12 \%$ partisipan mengalami peningkatan saat shift siang dan meningkat kembali saat shift malam. Sekitar $12 \%$ partisipan mengalami penurunan kadar $\alpha$-amilase saat shift siang jika dibandingkan shift pagi dan terus menurun saat shift malam. Sekitar 18\% partisipan mengalami penurunan kadar $\alpha$-amilase saat shift siang dan meningkat kembali saat shift malam.

Sekitar $18 \%$ partisipan yang menghasilkan kadar $\alpha$ amilase tertinggi saat shift malam. Sekitar 59\% partisipan yang menghasilkan kadar $\alpha$-amilase tertinggi saat shift siang, dan sekitar $24 \%$ partisipan yang menghasilkan kadar $\alpha$-amilase tertinggi saat shift pagi. Pola yang berbeda menunjukkan bahwa hal yang mempengaruhi tingkat stres kerja bukanlah shift kerja, namun oleh faktor lain.

Sistem shift yang diterapkan oleh PT. Kereta Api Indonesia (KAI) adalah sistem tiga shift kerja. Sistem tiga shift terbukti meningkatkan tingkat stres manusia jika dibandingkan dengan sistem kerja pada jam normal [42]. Namun jika dilihat dari pola shift, pola yang diterapkan oleh PT.KAI sesuai dengan ketentuan pada beberapa literatur. Pola sistem shift yang baik adalah pola maju (forward) dengan rotasi cepat (fast forward) dimana setelah melaksanakan shift malam diharuskan libur bekerja dua hingga tiga hari [6], [11], [43], [44].
Jam kerja untuk shift pagi dan siang adalah enam jam dan shift malam 12 jam. Saat shift malam terdapat waktu kosong tiga jam karena tidak ada perjalanan kereta, maka total bekerja pengendali yang efektif adalah sembilan jam. Rosa dan Bennert dalam [6] mengungkapkan bahwa risiko terjadinya kelelahan dan kecelakaan kerja pada waktu kerja lebih dari delapan jam akan semakin besar. Saat shift pagi dan siang jam kerja kurang dari delapan jam, namun tingkat kesibukan yang sangat tinggi memungkinkan meningkatnya tingkat stres pekerja. Grandjean, dkk. [17] mengungkapkan bahwa situasi dan kondisi kerja yang tinggi atau kritis lah yang dapat menimbulkan stres kerja. Tingkat kesibukan tersebut dapat diihat dari waktu istirahat antar kereta.

Selama bekerja dalam satu shift, pengendali tidak memiliki waktu istirahat tertentu, hanya saat selang waktu kosong antar kereta satu dengan kereta berikutnya. Rata-rata selang waktu kosong untuk shift pagi dan siang adalah 10 menit, sedangkan untuk shift malam adalah 17 menit. Pada saat shift pagi, selang waktu kosong tercepat antar kereta adalah dua menit, sedangkan untuk shift siang dan malam adalah satu menit. Selang waktu terlama antar kereta untuk shift pagi adalah 40 menit, untuk shift siang adalah 36 menit sedangkan untuk shift malam hingga tiga jam (dikarenakan tidak ada perjalanan kereta api saat tengah malam). Dapat dilihat bahwa tingkat kesibukan pengendali saat shift siang paling tinggi jika dibandingkan shift pagi dan malam. Hal ini selaras dengan hasil pengukuran yang menunjukkan bahwa shift siang menghasilkan kadar amilase tertinggi.

Pengendali kereta api Indonesia memiliki tuntutan kerja yang tinggi. Para pekerja dituntut agar selalu konsentrasi, teliti, fokus, dapat berpikir dan bertindak cepat dalam mengatur perjalanan kereta. Selain mengatur perjalanan, pengendali pun harus selalu siap berkomunikasi dengan bagian lain seperti petugas wesel, ataupun dengan masinis. Di sela-sela pekerjaan mengatur perjalanan, para pekerja diharuskan membuat catatan administrasi mengenai ketepatan waktu perjalanan kereta api secara manual. Berbeda dengan pengendali kereta api, contohnya adalah di Australia [2], pekerjaan pengendali kereta api Indonesia tidak banyak dibantu oleh teknologi tinggi.

Di samping itu, sekitar $88 \%$ partisipan telah menghasilkan nilai kadar amilase yang tinggi bahkan sebelum mulai bekerja. Hal ini dapat disebabkan oleh lokasi tempat tinggal. Hampir $65 \%$ partisipan membutuhkan waktu lebih dari 30 menit untuk sampai ke tempat kerja, bahkan tidak sedikit pula partisipan mengeluhkan jalanan macet dan cuaca yang panas. Sekitar $10 \%$ partisipan memiliki pekerjaan lain selain sebagai pengendali dan memiliki kebiasan berolahraga sebelum bekerja. Pada saat penelitian berlangsung, terdapat kondisi yang di luar akitivitas normal. Terdapat kereta yang bermasalah sehingga seluruh perjalanan terganggu sehingga pengendali mengatur ulang kembali alur perjalan dari dan ke luar stasiun. Hal tersebut memungkinkan menambah tekanan kepada pengendali.

Kepribadian serta gaya hidup dapat mempengaruhi tingkat stres manusia [6]. Hampir 47\% dari seluruh partisipan memiliki kebiasaan merokok dan sekitar $41 \%$ 
memiliki kebiasaan minum kopi. Pada penelitian kali ini, partisipan diharapkan menahan makan, minum, dan merokok minimal satu jam sebelum diambil pengukuran. Dalam menahan makan, partisipan tidak terlalu mengalami kesulitan, namun untuk menahan minum kopi dan merokok, partisipan cukup kesulitan, terutama dalam hal merokok. Para partisipan merasa gelisah disaat tidak merokok walau hanya satu jam. Hal tersebut dapat menjadi penyebab naiknya kadar amilase karena partisipan merasa sedikit tertekan atau gelisah.

Kondisi lingkungan pun dapat mempengaruhi tingkat stres kerja ([15], Luk, 2009 dalam [19]). Kondisi lingkungan di tempat kerja cukup dekat dengan peron sehingga kereta api baik yang datang maupun pergi terdengar sangat jelas. Selain itu getaran yang dihasilkan oleh kereta sangat terasa. Faktor lain seperti status menikah atau pun jumlah anak (Baker dkk., 2004 dalam [45]) mungkin saja dapat mempengaruhi tingkat stress para pengendali. Namun, faktor-faktor tersebut tidak dibahas dalam penelitian kali ini

Penggunaan alat pengukuran cocorometer pada penelitian ini dilakukan berdasarkan hasil validasi yang telah dilakukan di Jepang [28], [34] beserta rentang klasifikasi yang telah ditetapkan. Namun, belum dilakukan validasi terhadap alat cocorometer di Indonesia. Perbedaan negara beserta budaya tidak menutup kemungkinan dapat menghasilkan perbedaan. Penelitian ini merupakan penelitian di lapangan langsung. Meskipun telah diusahakan sebaik mungkin agar dapat mengontrol faktor-faktor yang dirasa dapat mempengaruhi hasil penelitian, namun pada kenyataannya, eksperimen lapangan tetap sulit untuk dilakukan pengontrolan $100 \%$.

\section{KESIMPULAN}

Shift kerja tidak mempengaruhi tingkat stres kerja. Hal yang menarik pada penelitian ini adalah tingginya tingkat stres kerja pengendali di seluruh shift, baik shift pagi, siang, maupun malam. Hal ini menunjukkan bahwa tanpa dipengaruhi oleh sistem shift, pengendali kereta api Indonesia telah merasakan stres kerja yang tinggi.

Sistem shift yang telah diterapkan tidak terlalu bertentangan dengan ketentuan yang ada pada beberapa literatur. Tingginya tingkat stres kerja dapat dipengaruhi oleh faktor lain, seperti tuntutan kerja yang tinggi yang pada akhirnya menghasilkan beban kerja yang tinggi, kondisi lingkungan, maupun faktor individu masing-masing seperti kepribadian, status ataupun kehidupan rumah. Berdasarkan hasil penelitian ini, mungkin pengaturan ulang shift kerja tidak begitu diperlukan, namun tuntutan kerja, beban kerja ataupun faktor individu sebaiknya ditinjau kembali.

Untuk penelitian selanjutnya dapat dilakukan dengan melakukan validasi terhadap alat ukut cocorometer pada masyarakat Indonesia. Hal ini disebabkan adanya kemungkinan perbedaan yang dihasilkan akibat adanya perbedaan negara serta budaya.

\section{UCAPAN TERIMA KASIH}

Peneliti sangat berterimakasih kepada jajaran staf PT.Kereta Api Indonesia yang telah memberi ijin dan bekerja sama dalam penelitian ini.

\section{DAFTAR PUSTAKA}

[1] Naweed, Anjum, Investigation into the skills of modern and traditional train driving. Applied Ergonomics, Volume 45,2014, pp. 462-470

[2] Dorrian, J., Baulk. S. D., dan Dawson, D., Work Hours, Workload, Sleep And Fatigue In Australian Rail Industry Employees, Applied Ergonomics, Volume 42, 2010, pp. 202-209.

[3] Jay, S. M., Dawson, D., Ferguson, S. A., dan Lamond, D., Driver Fatigue Extended Rail Operations, Applied Ergonomics, Volume 39, 2008, pp.623-620.

[4] Dorrian, J., Roach, G.D., Fletcher, A., dan Dawson, D., Simulated Train Driving : Fatigue, Self-Awareness And Cognitive Disengangement, Applied Ergonomics,Volume 38,2006, pp. 155-166

[5] Elfering,A., Grebner,S., Haller, M., RailwayController-Perceived Mental Workload, Cognitive Failure And Risky Commuting, Ergonomics, Volume 55, Number 12, 2012, pp. 1463-1475.

[6] Bridger, R.S., Introduction to Ergonomics, $3^{\text {rd }} \mathrm{ed}$, Taylor dan Franscis group, London, 2008.

[7] Mc. Lauglin, Jessica L., Stress, Fatigue, and Workload : Determining The Combined Effect On Human Performance. Tesis, Industrial Engineering and Management System, University of Central Florida, Florida, 2007.

[8] Ashberg, Elizabeth, Dimension Of Fatigue In Different Working Populations. Scandinavian Journal of Psychology, Volume 41, 2000, pp. 231-241.

[9] Ashberg, Elizabeth, Perceived Fatigue Related To Work. ISBN 91-7135-830-5, 1998.

[10] Goswani, R., Jena. R. K., dan Mohapatra, B. B., Effect Of Shift Work On Health: A Review, International Journal Research in Management, Volume 3, Number 2,2012, pp. 2249-5908

[11] Health dan Safety Executive, Managing Shiftwork, Health and Safety Guidance, HSE 09/09, 2006

[12] Nagai, M., Morikawa, Y., Kitaoka, K., Nakamura, K., Sakurai, M., dkk., Effects Of Fatigue On Immune Function In Nursing Performing Shift Work, Journal of Occuppational Health, Volume 53, 2011, pp. 312-319.

[13] Wilkinson, R., Allison, S., Feeney, M., dan Zaminska, Z., Alertness Of Night Nurses: Two Shift Systems Compared, Ergonomics, Volume 32, Number 3,2007, pp. 281-292.

[14] Rameshbabu, A., Reddy, D. M., dan Fleming, R., Correlates Of Negative Physical Health In Call Center Shift Workers, Applied Ergonomics, Volume 44, 2012, pp. 350-354. 
[15] Cervinka, Renata, Night Shift Dose And Stress At Work, Ergonomics, Volume 36, 2007, pp. 155-160

[16] Gerber, M., Hartmann, T., Brand, S., Trachsler, E. D., dan Puhse, U., The Relationship Between Shift Work, Perceived Stress, Sleep And Health In Swiss Police Officers, Journal of Criminal Justice, Volume 38, 2010, pp. 1167-1175.

[17] Grandjean, E. P., Wotzka, G., Schaad, R., dan Gilgen. A., Fatigue And Stress In Air Traffic Controller, Ergonomics, Volume 14, Number 1, 2007, pp. 159-165

[18] Wilkinson, R., Allison, S., Feeney, M., dan Zaminska, Z., Alertness Of Night Nurses: Two Shift Systems Compared, Ergonomics, Volume 32, Number 3,2007, pp. 281-292.

[19] Agyemang, C.B., Nyanyofio, J.G., Gyamfi, G.D., Job Stress, Sector Of Work And Shft Work Pattern As Correlates Of Worker Health And Safety : A Study Pf A Manufacturing Company In Ghana, International Journal of Business and Management, Volume 9 , Number 7, 2014, pp.59-69

[20] Nagai, M., Morikawa, Y., Kitaoka, K., Nakamura, K., Sakurai, M., dkk., Effects Of Fatigue On Immune Function In Nursing Performing Shift Work, Journal of Occuppational Health, Volume 53, 2011, pp. 312-319.

[21] Ljosa, C.H dan Lau, B., Shiftwork In The Norwegian Petroleum Industry : Overcoming Difficulties With Family And Social Life-A Cross Sectional Study, Journal of Occupational Medicine and Toxicology, Volume 4, Number 22, 2009.

[22] Ozdemir PG, Selvi Y, Ozkol H, Aydin A, Tuluce Y., The Influence Of Shift Work On Cognitive Fuctions And Oxidative Stress, Psychiatry Research, Volume 210, 2013, pp. 1219-1225.

[23] Pokorny, M. L. I., Blom, D. H. J., dan Leeuwen, P. V., Shift, Duration Of Work And Accident Risk Of Bus Driver, Ergonomics, Volume 30, Number 1, 2007, pp. 61-88.

[24] Coffey, L.C., Skipper Jr, J.K., Jung RN, F.D., Nurses And Shift Work : Effects On Job Performance And JobRelated Stress, Journal of Advanced Nursing, Volume 13, Number 2, 2006, pp. 245-254.

[25] Harma,M., Sallinen, M., Ranta, R., Mutanen, P., dan Muller, K., The Effect Of An Irregular Shift System On Sleepiness At Work In Train Drivers And Railway Traffic Controller, J. Sleep Res, Volume 11, 2002, pp. 141-151.

[26] Park, Jungwee, Work Stress and Job Performance, [Katalog], 75-001-XIE. Kanada, 2007

[27] Srivastava, Urmila R., Shift Work Related To Stress, Health And Mood States- A Study Of Dairy Workers, Journal of Health Management, Volume 12, Number 2, 2010, pp. 173-200.

[28] Yamaguchi, M., Kanemori, T., Kanemaru, M., Takai, N., Mizuno, Y., dkk., Performance Evaluation Of Salivary Amilase Activity Monitor, Biosensors and Bioelectronics, Volume 20, 2004, pp. 491-497.
[29] Bashir, U.dan Ramay,M. I., Impact Of Stress On Employees Job Performance A Study On Banking Sector Of Pakistan, International Journal of Marketing Studies, Volume 2, Number 1, 2010.

[30]Zurika, Abida, Evaluasi Kelelahan Mental dan Stres pada Sopir Bus Jarak Jauh. Tugas Akhir Tidak Terpublikasi, Program Jurusan Teknik dan Manajemen Industri, Institut Teknologi Bandung, 2012.

[31] Nater, U. M., Rohleder, N., Gaab, J., Berger, S., Jud, A., dkk., Human Salivary Alpha-Amilase Reactivity In Psychososial Stress Paradigm, International Journal of Psycho-Physiology, Volume 55, 2004, pp. 333-342..

[32] Behringer, V., Deschner, T., Mostl, E., Selzer, D., dan Hohmann, G., Stress Affect Air Liur Alpha-Amilase Activity In Bonobos, Physiologi and Behaviour, 2011, Volume 105,pp. 476-482.

[33] Murai, K., Wakida, S., Miyado, T., Fukushi, K., dan Hayashi, Y., Basic Study Of A Ship Navigators Stress Using Salivary Amilase Activity, IEEJ Transactions non Electrical and Electronic Engineering,Volume 4, 2009, pp. 680-682.

[34] Yamaguchi, M., Deguchi, M., Wakasugi, J., Ono, S., Takai, N., dkk., Hand-Held Monitor Of Symphatetic Nervous System Using Air Liur Amilase Activity And Its Validation By Driver Fatigue Assessment, Biosensors and Bioelectronics, Volume 21,2006, pp. 1007-1014

[35] Yamaguchi, M., Kanemori, T., Kanemaru, M., Mizuno, Y., dan Yoshida, H., Correlation Of Stress And Salivary Amilase Activity, Japanese Journal of Medical Electronics and Biological Engineering,Volume 39, Number 3, 2001, pp. 234-239.

[36] Mulribe, B. L., Sheehan, M.F., Bureel, L.M., dan Matthews, M.D., Measuring Stress And Ability To Recover From Stress With Salivary A-Amylase Levels, Research Report United States Military Academy, New York, USA, 2011.

[37] Kaida, K., Takahashi, M., Akestedt, T., Nakata, A., Otsyka, T., Haratani, T., dkk., Validation Of Karolinska Sleepness Scale Against Performance And EEG Variables, Clinical Neurophysiology, Volume 117, 2006, pp. 1574-1581.

[38] Robles, T. F., Shetty, V., Zigler, C. M., Glover, D. A., Elashoff, D., Murphy, D., \& Yamaguchi, M., The Feasibility Of Ambulatory Measurement Of Salivary Alpha Amylase: Relationships With Self-Reported And Naturalistic Psychological Stress, Biological Psychology, Volue 86, 2011, Pp. 50-56.

[39]Loh, S., Lamond, N., Dorrian, J., Roach, G., dan Dawson, D., The Validity Of Physchomotor Vigilance Tasks Of Less Than 10 Minutes Duration, Behaviour Research Methods, Instruments dan Computers, Volume 36, Number 2, 2004, pp. 339-346.

[40] Demsar, J., Statistical Comparisons Of Classifiers Over Multiple Data Sets., Journal of Machine Learning Research, Volume 7, 2006, pp. 1-30. 
[41]Newsom, Jason, Post Hoc Tests. Portland State University, 2006

[42] Harada, H., Suwazono, Y., Sakata, K., Okubo, Y., Oishi, M., Uetani, M., dkk., Three-Shift Ystem Increases Job Related Stress In Japanese Workers, Journal of Occupational Health, Volume 47, 2005, pp. 397-404.

[43] Hesselink, J. K., Leede, J.D., dan Goudswaard, A., Effect Of The New Fast Forward Rotating Five-Shift Roster At A Dutch Steel Company, Ergonomics, Volume 53, Number 6, 2010, pp.727-738.

[44] Knauth, P.,dan Hornberger, S., Preventive And Compensatory Measures For Shift Workers, Occupational Medicine, Volume 1, Number 53, 2003, pp. 109-116.

[45] Ryan, B., Wilson, J. R., Sharples, S., Kenvyn, F., dan Clarke, T., Rail Signallers Assessment Of Their Satisfaction With Different Shift Work System, Ergonomics, Volume 51, Number 11, 2008, pp. 16561671. 